\title{
Stimulation of Gonadal Steroid Synthesis by Chronic Excess of Adrenocorticotropin in Patients with Adrenocortical Insufficiency
}

\author{
H. Vierhapper, P. Nowotny, and W. WaldhäusI \\ Division of Clinical Endocrinology and Diabetes Mellitus, I. Medizinische Universitätsklinik, A-1090 Wien, Austria
}

\begin{abstract}
Analysis of 24-h urinary steroid excretion was performed by capillary gas chromatography in six patients (five men, one woman) with adrenocortical insufficiency. Ten healthy subjects (five men, five women) served as controls. A complete absence of all 21-hydroxylated steroid metabolites was seen in patients with adrenocortical insufficiency, whereas the excretion of several steroids lacking hydroxylation in the 21-position (pregnenolone, pregnenetriol, and 11-ketoandrosterone) was markedly increased. In addition, the presence of $11 \beta$-hydroxyandrosterone was confirmed by mass-spectrometry in the urine of three patients. This pattern of steroid excretion was unchanged in patients with adrenocortical insufficiency, both after stimulation by 1-24 adrenocorticotropin (ACTH) and after short-term (3-d) suppression with dexamethasone. We conclude that patients with adrenocortical insufficiency present a pattern of steroid excretion characterized by the absence of 21 -hydroxylated metabolites. In the absence of functional adrenocortical tissue, long-term pathologically elevated concentrations of ACTH apparently stimulate early steps of steroid synthesis, most likely in the gonads. In addition, the presence of 11-hydroxylated steroid metabolites (11-ketoandrosterone, 11 $\beta$-hydroxyandrosterone) in the urine of patients with adrenocortical insufficiency demonstrates that chronic ACTH excess in this disorder may induce some activity of 11 $\beta$-hydroxylase, an enzyme not found in the gonads under physiological conditions.
\end{abstract}

\section{Introduction}

The simultaneous evaluation of major urinary steroid metabolites by capillary gas chromatography $(1,2)$ comprehensively characterizes steroid production in man. Since a differentiation of metabolites derived from adrenocortical or gonadal steroid synthesis is not possible from determinations performed under basal conditions, dynamic tests of adrenocortical function (i.e., stimulation by adrenocorticotropin [ACTH] or suppression by exogenous glucocorticoids) are used to characterize the contribution of the adrenal cortex to overall steroid secretion. The interpretation of the results thus obtained relies on the assumption that these maneuvers interfere with adrenal, but not with gonadal, steroid synthesis. Although it is undisputed that ACTH

Please address correspondence to Dr. Vierhapper, Division of Clinical Endocrinology and Diabetes Mellitus, I. Medizinische Universitätsklinik, Lazarettgasse 14, A-1090 Wien, Austria.

Received for publication 20 August 1984 and in revised form 26 November 1985.

J. Clin. Invest.

(C) The American Society for Clinical Investigation, Inc. $0021-9738 / 86 / 04 / 1063 / 08 \quad \$ 1.00$

Volume 77, April 1986, 1063-1070 predominantly influences the function of the adrenal cortex, an additional effect on gonadal steroid production has not yet been excluded. Patients with adrenocortical insufficiency provide an excellent model from which to study the effect of markedly increased endogenous concentrations of ACTH on gonadal steroid production in the absence of functioning adrenocortical tissue. In the present investigation we have compared steroid excretion rates in patients having adrenocortical insufficiency with those of healthy controls, both under basal conditions as well as after additional stimulation with exogenous ACTH 1-24 and after suppression with dexamethasone.

\section{Methods}

Healthy subjects. The subjects were five healthy female volunteers, aged 19-27 yr, who had not taken oral contraceptives for at least $6 \mathrm{mo}$, and five healthy male volunteers, aged 21-28 yr. All subjects were within $\pm 10 \%$ of their ideal body weight (according to Metropolitan Life Insurance Tables). The aim and potential risks of the investigation were explained to each subject and written consent was obtained in each case. In healthy women, the study was begun between the fifth and the seventh day of the menstrual cycle. Following the collection of a 24-h urine for the determination of steroid excretion, an indwelling catheter was inserted into an antecubital vein and $0.25 \mathrm{mg}$ synthetic ACTH (1-24 ACTH, Synacthen, $0.25 \mathrm{mg}=100 \mathrm{IU}$; CIBA-GEIGY Ltd. Basle, Switzerland) was administered at 8:00 a.m. as an intravenous bolus. This was followed by a continuous infusion $(3 \mathrm{ml} / \mathrm{h} ; t=8 \mathrm{~h})$ containing $0.25 \mathrm{mg} 1-24$ ACTH in $24 \mathrm{ml}$ of $0.9 \% \mathrm{NaCl}$ solution. On days 3-6 of the experiment the subjects were treated with oral dexamethasone $(0.5 \mathrm{mg}$ four times a day; Schering A.G., Berlin, Federal Republic of Germany), but not with intravenous ACTH. A 24-h urine (8:00 a.m.-8:00 p.m.) was collected for the determination of urinary steroid excretion on day 1 (basal), day 2 (ACTH), and day 5 (dexamethasone) of the experiment. Blood samples for the determination of plasma concentrations of cortisol, 21-deoxycortisol and 11-ketoandrostenedione, pregnenolone, and 17-hydroxypregnenolone were obtained before the infusion of ACTH. Plasma concentrations of cortisol were also determined after the administration of ACTH and of dexamethasone.

Patients with adrenocortical insufficiency. Six patients with adrenocortical insufficiency (five men, aged 26-48 yr, and one postmenopausal woman, aged $55 \mathrm{yr}$ ) consented to participate in the study. ${ }^{131}$ I-cholesterol scanning failed in all patients to reveal the presence of functional adrenocortical tissue. Adrenocortical insufficiency was of autoimmune origin in four patients and due to bilateral adrenalectomy for Cushing's disease in two cases. Pituitary surgery had not been performed on any of these patients. The patients had been on continuous glucocorticoid (37.5-50.0 $\mathrm{mg}$ cortisone acetate/d divided into two doses) and mineralocorticoid (0.05-0.1 mg 9 $\alpha$-fluoro-hydrocortisone/d) replacement therapy for 2$17 \mathrm{yr}$ before this investigation. Nevertheless, supranormal concentrations of $\mathrm{ACTH}(>100->1,000 \mathrm{pg} / \mathrm{ml}$; normal $<60 \mathrm{pg} / \mathrm{ml}$ ) were found in each patient when estimated during routine controls on an outpatient basis. For the purpose of this study the patients were admitted to the hospital and taken off their individual substitution therapy. Consecutively, electrolyte equilibrium was monitored daily and maintained by intravenous administration of $0.9 \%$ saline. $84 \mathrm{~h}$ after the last dose of the respective substitution therapy the patients received an intravenous bolus and an 
infusion of 1-24 ACTH as described above for the healthy volunteers. Subsequently each patient was given $0.5 \mathrm{mg}$ dexamethasone four times a day and $0.05 \mathrm{mg} 9 \alpha$-fluoro-hydrocortisone/d by mouth for $3 \mathrm{~d}$. A 24$\mathrm{h}$ urine (08:00-08:00 h) for the determination of steroid excretion was collected under basal conditions (i.e., from 60 to $84 \mathrm{~h}$ after withdrawal of substitution therapy) during ACTH stimulation and on the third day of reinstituted glucocorticoid (dexamethasone) therapy. Blood samples for the determination of plasma concentrations of cortisol were drawn at the beginning of each urine-collecting period and at the end of the ACTH infusion. Concentrations of ACTH, of 21-deoxycortisol, of 11ketoandrostenedione, of pregnenolone, and of 17-hydroxypregnenolone were obtained before the infusion of ACTH. Concentrations of ACTH were also estimated after the administration of dexamethasone.

Reference steroids. Reference steroids were purchased from Steraloids Inc., Wilton, NH; and from Makor Chemicals, Jerusalem, Israel. Purity was checked by controlling melting point in each case.

Radioimmunoassays. For the simultaneous radioimmunologic determination of cortisol, 21-desoxycortisol, and 11-ketoandrostenedione, $2.0 \mathrm{ml}$ of plasma were diluted with $8.0 \mathrm{ml} \mathrm{H}_{2} \mathrm{O}$. To determine recoveries $20,000 \mathrm{dpm}$ of $\left[{ }^{3} \mathrm{H}\right]$ cortisol (NET 396 , specific activity $115 \mathrm{Ci} / \mathrm{mmol}$; New England Nuclear, Boston, MA), $1,000 \mathrm{dpm}$ of $21-\left[{ }^{3} \mathrm{H}\right]$ desoxycortisol (specific activity $43 \mathrm{Ci} / \mathrm{mmol}$; Amersham International, Amersham, Buckinghamshire, England), and $10,000 \mathrm{dpm}$ of $\left[{ }^{3} \mathrm{H}\right] \mathrm{DOC}$ (specific activity $42 \mathrm{Ci} / \mathrm{mmol}$; Amersham International) were added to each sample. $\left[{ }^{3} \mathrm{H}\right] \mathrm{DOC}$ was used to estimate the recovery of 11 -ketoandrostenedione, since the latter is not available in a labeled form and shows a chromatographic behavior in the chromatographic system we employed which is identical to that of DOC. Subsequently the samples were extracted with $150 \mathrm{ml}$ of cold $\mathrm{CH}_{2} \mathrm{Cl}_{2}$ and the organic extract was washed once with $10 \mathrm{ml}$ of cold $0.1 \mathrm{~N} \mathrm{NaOH}$ and twice with $10 \mathrm{ml}$ of cold $\mathrm{H}_{2} \mathrm{O}$. Separation of the steroids was achieved by thin-layer chromatography (benzene/ acetone $=75: 25$ ). For the simultaneous determination of pregnenolone and 17-hydroxypregnenolone, $2 \mathrm{ml}$ of plasma were diluted with $8 \mathrm{ml}$ of $\mathrm{H}_{2} \mathrm{O}$. To determine recoveries $10,000 \mathrm{dpm}$ of $\left[{ }^{3} \mathrm{H}\right]$ pregnenolone (specific activity $12 \mathrm{Ci} / \mathrm{mmol}$; Amersham Corp.) and $17-\left[{ }^{3} \mathrm{H}\right]$ hydroxypregnenolone (specific activity $19 \mathrm{Ci} / \mathrm{mmol}$; Amersham Corp.) were added to each sample. Subsequently the samples were extracted with $150 \mathrm{ml}$ of cold $\mathrm{CH}_{2} \mathrm{Cl}_{2}$ and the organic extract was washed with $10 \mathrm{ml}$ of cold $\mathrm{H}_{2} \mathrm{O}$. Separation of steroids was achieved by two-dimensional thin-layer chromatography (I: benzene/acetone, 75:25; II: ethylacetate/cyclohexane, 55:45). Radioimmunoassays were performed in triplicate using antisera against cortisol and 21-desoxycortisol obtained from Dr. Vecsei, Division of Pharmacology, University of Heildelberg, Heidelberg Federal Republic of Germany (3). Antisera for the determination of pregnenolone and 17 hydroxypregnenolone were obtained from Steranti Research Ltd., St. Albans, England; and from Radioassay Systems Laboratories, Inc., Carson, CA, respectively. Since no specific antiserum was available for the determination of 11-ketoandrostenedione, this steroid was determined using the cross-reactivity $(12.5 \%)$ of an antibody raised against androstenedione (Nr. XXA001; Steranti Research Ltd.). Cross-reactivity of this antibody against DOC is $<0.1 \%$. Furthermore, the behavior of androstenedione and 11-ketoandrostenedione permits complete separation in the used chromatographic system. Urinary concentrations of cortisol and plasma concentrations of ACTH were determined as previously reported (4).

Urine processing. Urine samples $(5 \mathrm{ml})$ of 24 -h collections were acidified to $\mathrm{pH} 5.2$ by addition of $0.2 \mathrm{~N} \mathrm{HCl}$. $\beta$-glucuronidase/arylsulfatase (20,000 Fisher units, Calbiochem-Behring Corp., La Jolla, CA) was added, the hydrolysis taking place at $37^{\circ} \mathrm{C}$. Hydrolysis did not affect $\mathrm{pH}$ values. After a total hydrolysis period of $24 \mathrm{~h}, 50,000 \mathrm{dpm}\left[{ }^{3} \mathrm{H}\right]$ cortisol were added to estimate recovery. The unconjugated steroids were extracted with three times $20 \mathrm{ml}$ of ethylacetate and the combined extract was washed once with $20 \mathrm{ml}$ of $0.1 \mathrm{~N} \mathrm{NaOH}$ and at least twice with $20 \mathrm{ml}$ of double distilled water until neutrality was reached. Anhydrous sodium sulfate (5-10 g) was then added to each sample. After $12 \mathrm{~h}$ the solvent was distilled off at $35^{\circ} \mathrm{C}$ at reduced pressure. The residue was transferred with $3 \times 1 \mathrm{ml}$ ethylacetate into a centrifuging tube and the solvent was evaporated in a stream of dry nitrogen at $35^{\circ} \mathrm{C}$.

Derivatization $(5,6)$. Samples were dissolved in $100 \mu \mathrm{l}$ of a solution of methoxyamine hydrochloride ( $2 \%$ in pyridine; Pierce Chemical Co., Rockford, IL) and heated at $80^{\circ} \mathrm{C}$ for $60 \mathrm{~min}$. After evaporation with dry $\mathrm{N}_{2}$ at $30^{\circ} \mathrm{C}, 100 \mu \mathrm{l}$ of a mixture of trimethylsilylimidazole, $\mathrm{N}, \mathrm{O}$ bis(trimethylsilyl)acetamide, and trimethylchlorosilane (3:3:2, TRI-SIL TBT; Pierce Chemical Co.) was added and the mixture was heated to $60^{\circ} \mathrm{C}$ for $20 \mathrm{~h}$. After evaporation to dryness by dry $\mathrm{N}_{2}\left(25^{\circ} \mathrm{C}\right.$, overnight $)$, $2 \mathrm{ml}$ of dichloromethane and $1.5 \mathrm{ml}$ of $0.1 \mathrm{~N} \mathrm{H}_{2} \mathrm{SO}_{4}$ were added to each sample, the mixture was shaken, and the aqueous (lighter) phase was pipetted off. The organic layer was washed once with $1 \mathrm{ml}$ of double distilled water. If the $\mathrm{pH}$ of the washing was $>7$, the organic layer was diluted with $1 \mathrm{ml} 0.1 \mathrm{~N} \mathrm{H}_{2} \mathrm{SO}_{4}$. The organic layer was then diluted with

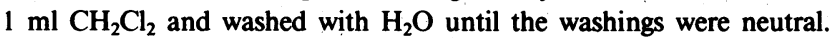
Sodium sulfate was added to the organic solutions and the samples were shaken for $20 \mathrm{~min}$ and centrifuged. The clear solutions were transferred into reactivials; the solvent was evaporated with dry $\mathrm{N}_{2}$ at room temperature and the residue was dissolved in $100 \mu$ l of a mixture of ethylacetate/n-hexane (9:1) containing $100 \mathrm{ng} / \mu \mathrm{l}$ of alkanes $n-\mathrm{C}_{24} \mathrm{H}_{50}$ and $n-\mathrm{C}_{32} \mathrm{H}_{66}$.

Recovery. $20 \mu$ l of each sample were measured in a $\beta$-counter (Packard Instruments Co., Delft, Netherlands). Mean recovery $(n=75)$ was $55.7 \pm 5.5 \%$.

Gas chromatography. Gas chromatography was carried out using a Packard Instrument Co. 428 gaschromatograph equipped with a $50 \mathrm{~m}$ OV-101 wall-coated open tubular column $(0.25 \mathrm{~mm}$ i.d., film thickness $0.25 \mu \mathrm{m}$, pretested at 180.000 effective plates), a solid injection device, and a flame ionization detector. $\mathrm{N}_{2}$ was used as a carrier gas with a flow rate of $\sim 0.8 \mathrm{ml} / \mathrm{min}$. After sample injection $\left(300^{\circ} \mathrm{C}\right)$, the temperature of the oven was immediately programmed between $180^{\circ} \mathrm{C}$ and $265^{\circ} \mathrm{C}$ at $0.4^{\circ} \mathrm{C} / \mathrm{min}$ followed by an isothermal run for $15 \mathrm{~min}$ at end temperature.

Steroid identification. Steroids were identified by comparison of retention times expressed as methylene units as determined by intrapolation between those of the alkanes $n-\mathrm{C}_{24} \mathrm{H}_{50}$ and $n-\mathrm{C}_{32} \mathrm{H}_{66}$; (Table I). Trivial names of steroid metabolites determined by gas chromatography and of the other steroids mentioned in this report are given in Table I.

Mass spectrometry. Positive identification of 11-hydroxyandrosterone was attempted by gas chromatography-mass spectrometry using a 5995 gas chromatography-mass spectrometry system equipped with a $25-\mathrm{m}$ fused silica capillary column coated with OV 101 stationary phase (Hewlett-Packard Co., Palo Alto, CA). The GC injector was maintained at $300^{\circ} \mathrm{C}$ and the oven was programmed from $180^{\circ} \mathrm{C}$ to $260^{\circ} \mathrm{C}$ at a rate of $1^{\circ} \mathrm{C} / \mathrm{min}$. Temperatures of the analyzer, transfer line, and ion source were kept at $180^{\circ} \mathrm{C}, 280^{\circ} \mathrm{C}$, and $150^{\circ} \mathrm{C}$, respectively, and the electron energy was $70 \mathrm{eV}$. To increase sensitivity it was necessary to determine 11-hydroxyandrosterone by selected ion monitoring, the instrument having been set to monitor the ions at $\mathrm{m} / \mathrm{e} 479\left(\mathrm{M}^{+}\right), \mathrm{m} / \mathrm{e} 449\left(\mathrm{M}^{+}\right.$ - 30), $\mathrm{m} / \mathrm{e} 448\left(\mathrm{M}^{+}-31\right)$, and $\mathrm{m} / \mathrm{e} 358\left(\mathbf{M}^{+}-121\right)$.

Calculation of steroid excretion. An automatic integrator $(3358 \mathrm{~A}$; Hewlett-Packard Co.) was used for the calculation of the area under the respective peaks. Response factors (f) for the two $n$-alkanes (f $\mathrm{C} 24$ and f C32) and for each reference steroid standard ( $\mathrm{St}$ ) were determined by their injection in varying amounts. These response factors were checked and adjusted regularly (i.e., after every 15 th injection of biological samples) by derivatizing and injecting defined mixtures of the reference compounds. Response factors for the two $n$-alkanes were practically identical (f C24, 1.05 \pm 0.18 ; f C32, 1.07 \pm 0.20 ) over the complete series of injections. It was unnecessary to introduce additional correction factors for the increasing elution temperatures. The excreted amounts of individual steroids were calculated by the following formula:

$\mathrm{mg} / 24 \mathrm{~h}=$ area $\times \mathrm{f} \mathrm{C24} \times \mathrm{f} \mathrm{St} \times 100 /$ recovery $(\%) \times$ dilution,

where area equals measured peak area; f $\mathrm{C} 24$ equals response factor for hydrocarbon C24 (provides for the actually injected amount); f St equals response factor for individual steroid; recovery equals the yield of the complete treatment of the samples before gas chromatography by measuring recovery of $\left[{ }^{3} \mathrm{H}\right]$ cortisol; and dilution equals the aliquotization of original urinary samples.

Sensitivity and precision. The sensitivity of the procedure varied according to the gas chromatography conditions used. Applying standard 
Table I. Trivial Names and Gas-chromatographic Characteristics of Evaluated Standard Steriod Compounds*

\begin{tabular}{|c|c|c|c|}
\hline No. & Steroid & Trivial name & $\begin{array}{l}\text { Methylation units } \\
\text { (as MO-TMS derivatives) }\end{array}$ \\
\hline 1 & & $n$ - $\mathrm{C}_{24}$-Alkane & 24.00 \\
\hline 2 & $5 \alpha$-Androstan-3 $\alpha$-ol-17-one & Androsterone & 25.09 \\
\hline 3 & $5 \beta$-Androstan-3 $\alpha$-ol-17-one & Etiocholanolone & 25.28 \\
\hline 4 & 5-Androsten-3 $\beta$-ol-17-one & Dehydroepiandrosterone & 25.68 \\
\hline 5 & $5 \alpha$-Androstan-3 $\beta$-ol-17-one & Epiandrosterone & 25.83 \\
\hline 6 & 5-Androsten-3 $\beta, 17 \beta$-diol & Androstenediol & 25.92 \\
\hline 7 & $5 \alpha$-Androstan-3 $\alpha$-ol-11,17-dione & 11-Ketoandrosterone & 26.01 \\
\hline 8 & 1,3,5(10)-Estratrien-3-ol-17-one & Estrone & 26.01 \\
\hline 9 & $5 \beta$-Androstan-3 $\alpha$-ol-11,17-dione & 11-Ketoetiocholanolone & 26.14 \\
\hline 10 & 4-Androsten-3,17-dione & Androstenedione & $26.19 / 26.24$ \\
\hline 11 & 1,3,5(10)-Estratrien-3,17 $\beta$-diol & Estradiol & 26.38 \\
\hline 12 & 4-Androsten-17 $\beta$-ol-3-one & Testosterone & 26.47 \\
\hline 13 & $5 \beta$-Pregnan-3 $\alpha$-ol-20-one & Epipregnanolone & 26.87 \\
\hline 14 & $5 \alpha$-Androstan-3 $\alpha-11 \beta$-diol-17-one & $11 \beta$-Hydroxyandrosterone & 26.96 \\
\hline 15 & $5 \beta$-Androstan-3 $\alpha$-11 $\beta$-diol-17-one & $11 \beta$-Hydroxyetiocholanolone & 27.13 \\
\hline 16 & $5 \beta$-Pregnan- $3 \beta$-ol-20-one & Pregnanolone & 27.15 \\
\hline 17 & $5 \alpha$-Pregnan-3 $3,20 \alpha$-diol & Allo-Pregnanediol & 27.42 \\
\hline 18 & $5 \beta$-Pregnan-3 $\alpha, 20 \alpha$-diol & Pregnanediol & 27.62 \\
\hline 19 & 5-Pregnen-3 $\beta$-ol-20-one & Pregnenolone & 27.67 \\
\hline 20 & $5 \beta$-Pregnan-3 $\alpha, 17 \alpha, 20 \alpha$-triol & Pregnanetriol & 27.95 \\
\hline 21 & 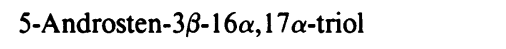 & $17 \alpha$-Androstenetriol & 28.16 \\
\hline 22 & 4-Pregnen-3,20-dione & Progesterone & $28.20 / 28.25$ \\
\hline 23 & 5-Androsten-3 $3,16 \alpha, 17 \beta$-triol & $17 \beta$-Androstenetriol & 28.41 \\
\hline 24 & $5 \beta$-Pregnan- $3 \alpha, 17 \alpha, 21$-triol-20-one & TH-“S” & 28.67 \\
\hline 25 & $5 \beta$-Pregnan-3 $\alpha, 21$-diol-20-one & TH-“DOC” & 28.76 \\
\hline 26 & $1,3,5(10)$-Estratrien-3,16 $\alpha, 17 \beta$-triol & Estriol & 28.76 \\
\hline 27 & $5 \alpha$-Pregnan-3 $\alpha, 21$-diol-20-one & Allo-TH-“DOC" & 28.91 \\
\hline 28 & $5 \alpha$-Pregnan- $3 \alpha, 17 \alpha, 21$-triol-20-one & Allo-TH-"S" & 29.02 \\
\hline 29 & $5 \beta$-Pregnan-3 $\alpha, 17 \alpha, 20 \alpha$-triol-11-one & Pregnanetriolone & 29.02 \\
\hline 30 & 5-Pregnen-3 $\beta, 17 \alpha, 20 \alpha$-triol & Pregnenetriol & 29.47 \\
\hline 31 & $5 \beta$-Pregnan-3 $\alpha, 17 \alpha, 21$-triol-11,20-dione & TH-“E” & 29.66 \\
\hline 32 & $5 \beta$-Pregnan-3 $\alpha, 21$-diol-11,20-dione & TH-“A” & 29.75 \\
\hline 33 & $5 \beta$-Pregnan-3 $\alpha, 11 \beta, 21$-triol-20-one & TH-“B” & 30.00 \\
\hline 34 & $5 \alpha$-Pregnan-3 $\alpha, 11 \beta, 21$-triol-20-one & Allo-TH-“B" & 30.12 \\
\hline 35 & $5 \alpha$-Pregnan-3 $\alpha, 17 \alpha, 21$-triol-11,20-dione & Allo-TH-“E” & 30.25 \\
\hline 36 & $5 \beta$-Pregnan-3 $\alpha, 11 \beta, 17 \alpha, 21$-tetrol-20-one & TH-“F” & 30.27 \\
\hline 37 & $5 \alpha-$ Pregnan-3 $\alpha, 11 \beta, 17 \alpha, 21$-tetrol-20-one & Allo-TH“F” & 30.37 \\
\hline 38 & $5 \beta$-Pregnan-3 $\alpha, 17 \alpha, 20 \alpha, 21$-tetrol-11-one & $\alpha$-Cortolone & 30.49 \\
\hline 39 & $5 \beta$-Pregnan-3 $\alpha, 17 \alpha, 20 \beta, 21$-tetrol-11-one & $\beta$-Cortolone & 30.77 \\
\hline 40 & $5 \beta$-Pregnan-3 $\alpha, 11 \beta, 17 \alpha, 20 \beta, 21$-pentol & $\beta$-Cortol & 30.77 \\
\hline 41 & 5 -Cholesten-3 $\beta$-ol & Cholesterol & 30.89 \\
\hline 42 & $5 \beta$-Pregnan-3 $\alpha, 11 \beta, 17 \alpha, 20 \alpha, 21$-pentol & $\alpha$-Cortol & 31.22 \\
\hline 43 & & $n$-C $\mathrm{C}_{32}$-Alkane & 32.00 \\
\hline
\end{tabular}

* Trivial names of other steroids mentioned in this paper:

4-Androsten-1 $1 \beta$-ol-3,17-dione

4-Androsten-3,11,17-trione

5-Pregnen-3 $\beta, 17 \alpha$-diol,20-one

4-Pregnen-11 $\beta, 17 \alpha$-diol-3,20-dione

4-Pregnen-17 $\alpha$-ol-3,20-dione

4-Pregnen-17 $\alpha, 21$-diol-3,11,20-trione

4-Pregnen-11 $\beta, 17 \alpha, 21$-triol-3,20-dione

4-Pregnen-11 $\beta, 21$-diol-3,20-dione

4-Pregnen,21-ol-3,20-dione

4-Pregnen-17 $\alpha, 21$-diol-3,20-dione

$11 \beta$-Hydroxyandrostenedione

11-Ketoandrostenedione

$17 \alpha$-Hydroxypregnenolone

21-Desoxycortisol

$17 \alpha$-Hydroxyprogesterone ("17OH-P”)

Cortisone ("E")

Cortisol ("F")

Corticosterone ("B")

Desoxycorticosterone ("DOC")

11-Desoxycortisol ("S") 
conditions sensitivity was $\sim 1$ ng per injected sample corresponding to about $0.02 \mathrm{mg}$ of steroid per $24 \mathrm{~h}$. The coefficient of variation for multiple determinations $(n=8)$ of the whole spectrum of standard compounds was $12 \pm 3 \%$ (range, $10-20 \%$ ).

Statistics. Data are presented as mean \pm SD. Student's $t$ test (twotailed) for matched and for unmatched pairs was used for statistical evaluation.

\section{Results}

In unsubstituted patients with adrenocortical insufficiency, plasma concentrations of cortisol were $1.1 \pm 0.5 \mu \mathrm{g} / \mathrm{dl}$ (controls, $6.8 \pm 2.2 \mu \mathrm{g} / \mathrm{dl}$ ). Concentrations of 11-ketoandrostenedione and of 21 -deoxycortisol were $64 \pm 18 \mathrm{ng} / \mathrm{dl}$ (controls, $279 \pm 139 \mathrm{ng} /$ $\mathrm{dl}$ ) and $2.0 \pm 0.3 \mathrm{ng} / \mathrm{dl}$ (controls, $5.1 \pm 1.0 \mathrm{ng} / \mathrm{dl}$ ) respectively, and the concentrations of pregnenolone and 17-hydroxypregnenolone were $38.2 \pm 14.2 \mathrm{ng} / \mathrm{dl}$ (controls, $53.3 \pm 6.2 \mathrm{ng} / \mathrm{dl}$ ) and $12.9 \pm 6.4 \mathrm{ng} / \mathrm{dl}$ (controls, $45.0 \pm 18.9 \mathrm{ng} / \mathrm{dl}$ ), respectively. Thus, when compared with healthy controls, mean estimated concentrations of cortisol, 11-ketoandrostenedione, 21-deoxycortisol, pregnenolone, and 17-hydroxypregnenolone in patients with adrenocortical insufficiency were $13,23,39,72$, and $29 \%$, respectively. In patients with adrenocortical insufficiency, plasma concentrations of cortisol were unchanged by the administration of ACTH $(1.5 \pm 0.7 \mu \mathrm{g} / \mathrm{dl}$; controls, $24.0 \pm 10.6 \mu \mathrm{g} / \mathrm{dl})$ and of dexamethasone $(0.6 \pm 0.2 \mu \mathrm{g} / \mathrm{dl}$; controls, $0.8 \pm 0.2 \mu \mathrm{g} / \mathrm{dl})$. Plasma concentrations of ACTH in patients with adrenocortical insufficiency were $968 \pm 410 \mathrm{pg} / \mathrm{ml}$ (range, $462-1670 \mathrm{pg} / \mathrm{ml}$ ) after withdrawal of substitution therapy and $151 \pm 144 \mathrm{pg} / \mathrm{ml}$ (range, $54-429 \mathrm{pg} / \mathrm{ml}$ ) after $3 \mathrm{~d}$ of dexamethasone by mouth.

Steroid excretion rates of healthy men, healthy women, and of patients with adrenocortical insufficiency are given in Table II. Comparable excretion rates of cholesterol were found in patients with adrenocortical insufficiency and in healthy controls. Urine samples of patients were characterized by a lack of all 21hydroxylated metabolites (TH-“A”, TH-“B”, allo-TH-“B”, TH"DOC", allo-TH-“DOC”, TH-“S”, allo-TH-“S”, TH-“E”, alloTH-“E”, TH-“F”, allo-TH-“F”, $\alpha$-cortol, $\beta$-cortol, $\alpha$-cortolone, and $\beta$-cortolone, Fig. 1). In addition, patients with adrenocortical insufficiency presented with a reduced excretion of androsterone, etiocholanolone, dehydroepiandrosterone, androstenediol, $11 \beta$ hydroxyetiocholanolone, 11 $\beta$-hydroxyandrosterone, 11-ketoetiocholanolone, pregnanediol, and allopregnanediol, whereas the mean excretion of pregnanetriol $(3.92 \pm 3.07 \mathrm{mg} / 24 \mathrm{~h})$, pregnenetriol $(2.22 \pm 2.47 \mathrm{mg} / 24 \mathrm{~h})$, pregnenolone $(1.85 \pm 2.47 \mathrm{mg} /$ $24 \mathrm{~h}$ ), and 11-ketoandrosterone (1.34 $\pm 1.64 \mathrm{mg} / 24 \mathrm{~h})$ was increased as compared with healthy controls. In regard to the low excretion rates, both in patients with adrenocortical insufficiency and in healthy controls, a comparison of the excreted amounts was not possible for the remaining compounds listed in Tables I and II. Finally, the excretion rates of cortisol in patients with adrenocortical insufficiency were $<0.5 \mu \mathrm{g} / 24 \mathrm{~h}$ after withdrawal of substitution therapy, during stimulation by ACTH, and after $3 \mathrm{~d}$ of dexamethasone by mouth. Whereas the administration of ACTH and of dexamethasone induced the expected changes in the excretion of steroid metabolites in healthy men and women, the respective excretion rates remained unchanged in patients with adrenocortical insufficiency (Table II).

Gas-chromatographic analysis indicated the presence of 11 hydroxyandrosterone in the urine of three patients with adrenocortical insufficiency. This was confirmed by additional mass spectrometry using selected ion monitoring. As shown in Fig. 2 for one single case the chosen characteristic ions were readily identified, both in a mixture of derivatized reference compounds and in the patient's urine.

\section{Discussion}

The prerequisite for the simultaneous estimation of a large number of urinary steroid metabolites has been provided by the development of glass capillary gas chromatography $(1,2)$. The variety of techniques and hydrolytic procedures used by different laboratories implies that the only valid reference material is a material obtained using that very method. In order to study the steroid excretion rates in patients with adrenocortical insufficiency, it was therefore pivotal to establish reference data in a group of healthy subjects. These data are included in this report.

Although the relative share of the gonads and the adrenal cortex in overall steroid production can easily be studied in patients with adrenocortical insufficiency, few such data have been reported as yet in this disorder (7-9).

Under physiological conditions the enzymes 21-hydroxylase, $11 \beta$-hydroxylase, and 18-hydroxylase are unique to the adrenal cortex, whereas other enzymes, such as $3 \beta$-steroid dehydrogenase, $17 \alpha$-hydroxylase, and the desmolases are shared by the adrenals and by the gonads and probably are controlled by a single gene (10). The lack of 21-hydroxylated steroid metabolites observed in the urine of our patients can therefore be easily deduced from the differences in the enzymatic equipment of the adrenal cortex as compared with that of the gonads, whereas the presence of two 11-hydroxylated metabolites, $11 \beta$-hydroxyandrosterone and 11-ketoandrosterone, and the elevated excretion of pregnenolone, pregnanolone, and pregnenetriol requires further discussion.

Although adrenal scanning is believed to be superior to other noninvasive techniques in the detection of adrenal rest tissue (11), the negative outcome of ${ }^{131}$ I-cholesterol scanning per se may not completely rule out this possibility in our patients. Additional evidence against a residual adrenal function is, however, provided by the lack of urinary cortisol and by plasma cortisol concentrations close to the lower limit of the used radioimmunological method. Finally, the increased excretion of some metabolites not requiring 21-hydroxylation (e.g., pregnanetriol and pregnenetriol) in the absence of all urinary 21 -hydroxylated metabolites and a similarly distorted relationship among the estimated plasma steroids implies that the site of steroid hormone production in our patients is characterized by a pattern of steroidogenesis different from that of normal adrenal tissue.

In the absence of functional adrenal tissue the presence of 11-hydroxylated steroid metabolites must be due to an extraadrenal 11-hydroxylase. Such a speculation may be based on the previous demonstration of an extraadrenal 21-hydroxylase (12) and of a hepatic $3 \beta$-steroid dehydrogenase (10). However, in regard to the increased excretion of early steroid metabolites mentioned above, a gonadal origin of $11 \beta$-hydroxylated steroids in our patients appears more likely. The minor alterations in gonadotropin secretion seen in patients with adrenocortical insufficiency (13) are not likely to account for these pronounced changes in steroid excretion.

Under the appropriate experimental conditions, ACTH, the tropic hormone of the adrenal, may stimulate both rat and human testicular cells at the molecular level in terms of RNA syn- 


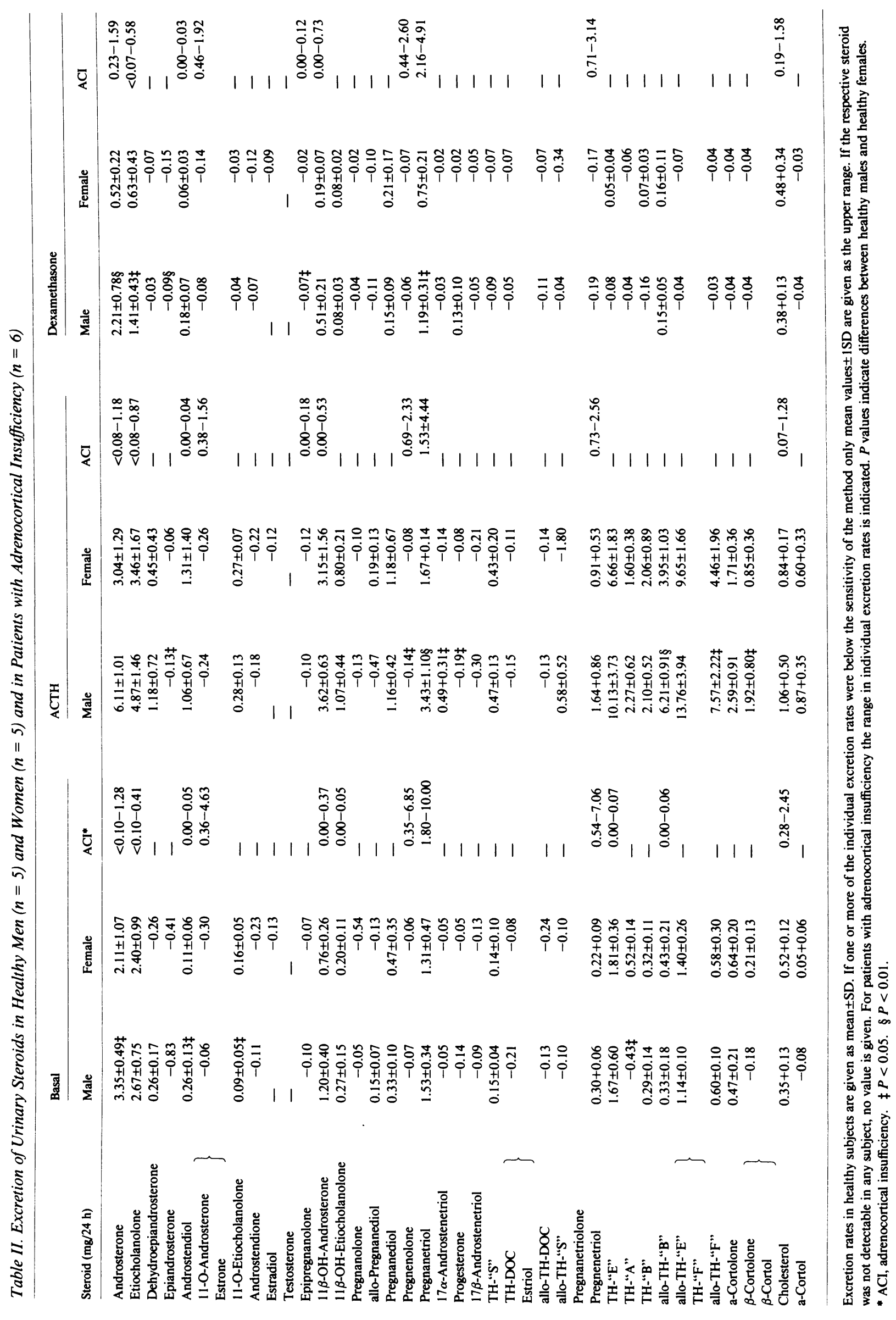




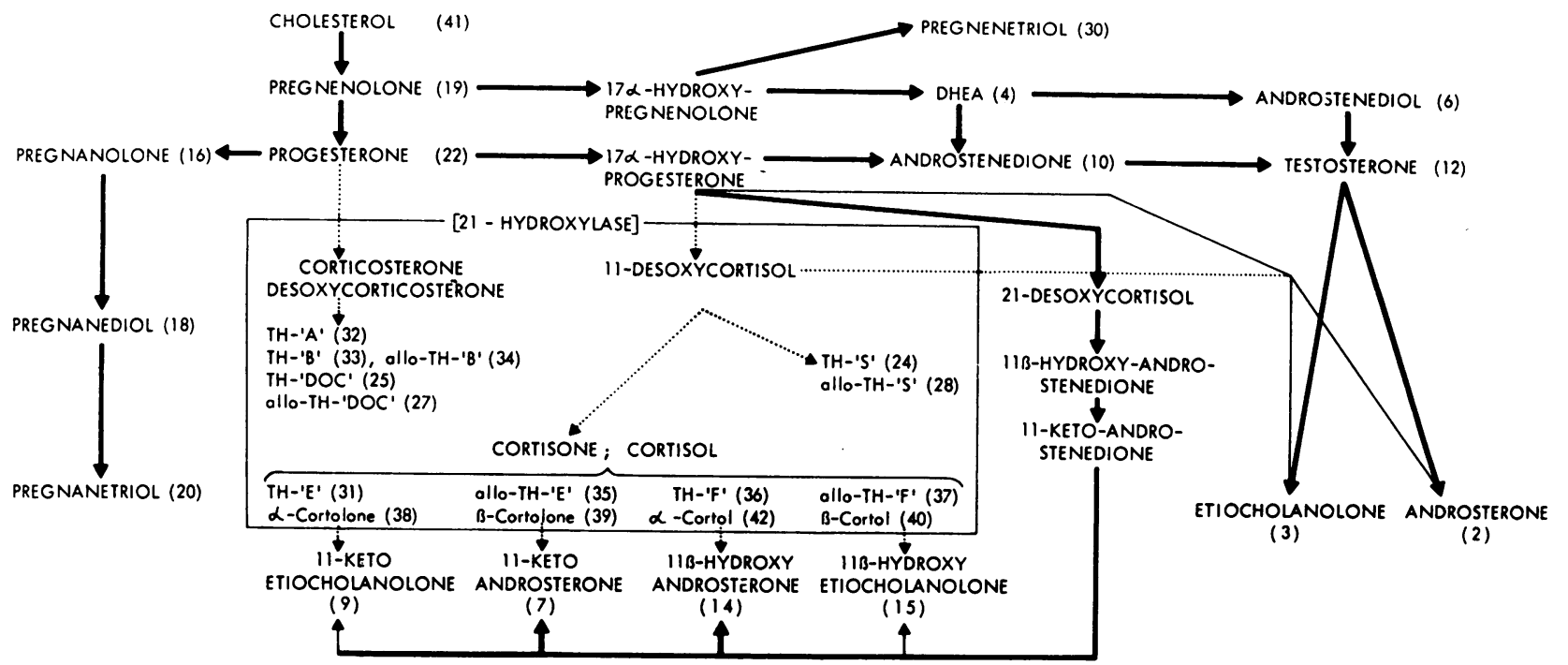

Figure 1. Simplified scheme of steroidogenesis in patients with adrenocortical insufficiency. The numbers in brackets refer to the numbering system of steroid standards given in Table I.

thesis and of steroid hormone synthesis (14). It appears possible that concentrations of ACTH elevated, as in our patients, for periods of several years may influence gonadal steroidogenesis in adrenocortical insufficiency.

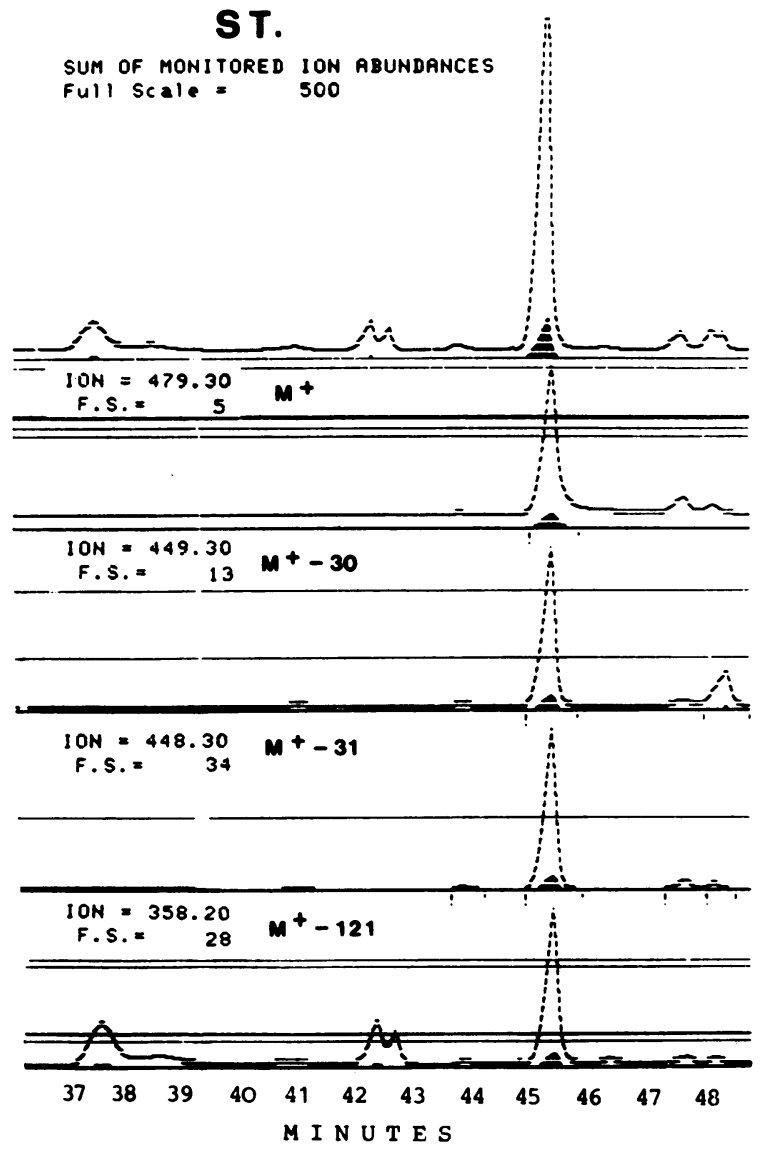

In the adrenal cortex the presence of elevated concentrations of ACTH for prolonged periods of time has been shown to alter the relative activities of the various steroid hydroxylases (15). Chronic overexposure to ACTH apparently modifies gonadal

P. SUM OF MONITORED ION ABUNDANCES
FUII SCAIE $=\quad 100$
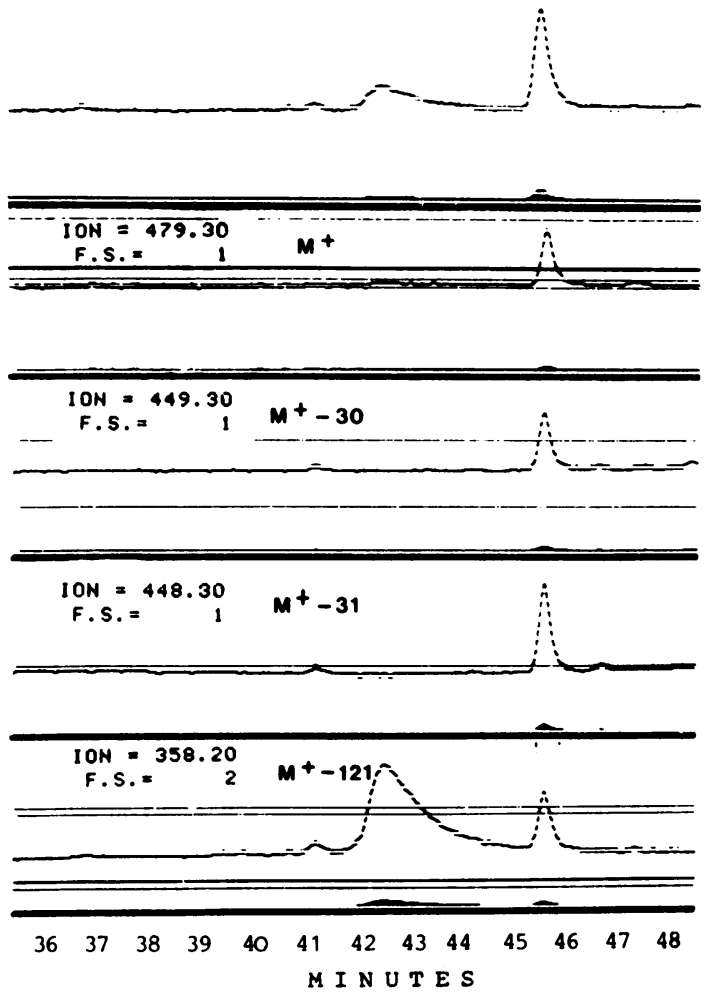

Figure 2. Identification of 11-hydroxyandrosterone by gas chromatography-mass spectrometry (selected ion monitoring) in a mixture of derivatized reference compounds (St.) and in the urine of a patient with adrenocortical insufficiency (P.). Plots of the following four ions are shown: $\mathrm{m} / \mathrm{e} 479\left(\mathrm{M}^{+}\right), \mathrm{m} / \mathrm{e} 449\left(\mathrm{M}^{+}-30\right), \mathrm{m} / \mathrm{e} 448\left(\mathrm{M}^{+}-31\right)$, and $\mathrm{m} / \mathrm{e} 358\left(\mathrm{M}^{+}-129\right)$. The abscissa represents the retention time (minutes). 
steroidogenesis in an analogous manner, thus explaining the increased excretion of early steroid metabolites not requiring 21hydroxylation. This would also imply that the attempt to qualify the origin of any given steroid as gonadal or adrenal by its absence or presence in patients with adrenocortical insufficiency (9) is an oversimplification. Steroid excretion rates remained unchanged in our unsubstituted patients during the administration of 1-24 ACTH and of dexamethasone, indicating that the additional administration of ACTH or the short-term partial suppression of endogenous ACTH by $2 \mathrm{mg}$ dexamethasone for $3 \mathrm{~d}$ is apparently of little relevance in this pathological situation. Concerning the presence of 11-hydroxylated metabolites, i.e., of $11 \beta$-hydroxyandrosterone and 11-ketoandrosterone, in the urine of patients with adrenocortical insufficiency, it should be remembered that some testicular tumors in patients with congenital adrenal hyperplasia and in adrenalectomized patients with Cushing's syndrome possess both $11 \beta$-hydroxylase and 21-hydroxylase activity in vitro (16-19). The question of whether these tumors arise from regular testicular tissue (20) or from adrenal remnants within the testes (21) is as yet unsettled (19), but prolonged exposure to markedly elevated concentrations of ACTH has generally been implied in their pathogenesis (17). Thus, during prolonged overexposure to ACTH, the human gonad is capable of producing 11-hydroxylated steroids.

Since the side chain at $\mathrm{C} 17$ found in $\mathrm{C}_{21}$ steroids orients the reduction of the double bond at $\mathrm{C} 4 / \mathrm{C} 5$ in the $5 \beta$ direction (22), $\mathrm{C}_{19} \mathrm{O}_{3}$ steroids with the $5 \beta$-configuration (i.e., 11-ketoetiocholanolone, and $11 \beta$-hydroxyetiocholanolone) are metabolites of $\mathrm{C}_{21}$ precursors such as cortisol. Compounds with the $5 \alpha$ configuration (i.e., 11-ketoandrosterone, $11 \beta$-hydroxyandrosterone) are derived from $11 \beta$-hydroxyandrostenedione and from $11-\mathrm{ke}$ toandrostenedione (22-24) via side-chain cleavage of 21-deoxycortisol. The synthesis of these steroids, therefore, requires the activity of $11 \beta$-hydroxylase, but not of 21 -hydroxylase. The assumed presence of $11 \beta$-hydroxylase in the gonads of our patients thus not only explains the observed excretion of $\mathrm{C} 11$-oxygenated steroids, but also the preponderance of the $5 \alpha$ - vs. the $5 \beta$-configurated metabolites.

The estimated plasma concentrations of 21-desoxycortisol and 11-ketoandrosterone are also in keeping with the presence of 11-hydroxylase activity in our patients, and it is of note that the reduction in the plasma concentrations of both steroids was less pronounced than that of cortisol. In regard to the elevated excretion rates of 11-ketoandrosterone, pregnanetriol, pregnenetriol, and pregnenolone, elevated plasma concentrations of the respective precursor steroids (i.e., 11-ketoandrostenedione, 21-desoxycortisol, pregnenolone, and 17-hydroxypregnenolone) might have been expected. This was clearly not the case and there is no ready explanation for this observation, although one might point out that plasma concentrations of steroids do not necessarily reflect the excretion rates of their metabolites, since both values also depend on the metabolic clearance rate of the respective precursor $(25)$.

Under physiological conditions both the adrenal cortex and the gonads contribute to the urinary excretion of 11-desoxy-17ketonic steroid metabolites (etiocholanolone, androsterone), although direct glandular secretion of both compounds is small (26). In our patients with adrenocortical insufficiency the lack of adrenal precursors apparently accounts for the diminished excretion of etiocholanolone and androsterone. The latter is in keeping with the $65 \%$ reduction in plasma androsterone as reported by others (26).
In conclusion, patients with adrenocortical insufficiency present a pattern of steroid excretion characterized by the complete absence of 21-hydroxylated, but not of 11-hydroxylated, metabolites. The obtained data suggest that chronic ACTH exposure may result in the activation of $11 \beta$-hydroxylase in the human gonad.

\section{Acknowledgment}

The valuable technical assistance of Ms. E. Nowotny is gratefully acknowledged.

\section{References}

1. Luyten, J. A., and G. A. F. M. Rutten. 1974. Analysis of steroids by high resolution gas-liquid chromatography. II. Application of urinary samples. J. Chromatogr. 91:393-406.

2. Pfaffenberger, C. D., and E. C. Horning. 1975. High resolution biochemical gas-chromatography. Determination of human steroid metabolites using glass open tubular capillary columns. J. Chromatogr. 112: 581-594.

3. Milewicz, A., P. Vecsei, S. Korth-Schütz, D. Haack, A. Rösler, K. Lichtwald, S. Lewicka, and G. von Mittelstaedt. 1984. Development of plasma 21-deoxycortisol radioimmunoassay and application to the diagnosis of patients with 21-hydroxylase deficiency. J. Steroid Biochem. 21:185-191.

4. Waldhäusl, W., K. Herkner, P. Nowotny, and P. Bratusch-Marrain. 1978. Combined $17 \alpha$ - and 18-hydroxylase deficiency associated with complete male pseudohermaphroditism and hypoaldosteronism. J. Clin. Endocrinol. Metab. 46:236-246.

5. Chambaz, E. M., and E. C. Horning. 1969. Conversion of steroids to trimethylsilyl derivatives for gas phase analytical studies: reaction of silylating reagents. Anal. Biochem. 30:7-24.

6. Shackleton, C. H. L., and J. W. Honour. 1976. Simultaneous estimation of urinary steroids by semiautomated gas chromatography. Investigation of neo-natal infants and children with abnormal steroid synthesis. Clin. Chim. Acta. 69:267-283.

7. Abraham, G. E., and Z. H. Chakmakjian. 1973. Serum steroid levels during the menstrual cycle in a bilaterally adrenalectomized woman. J. Clin. Endocrinol. Metab. 37:581-587.

8. Worgul, T. J., R. J. Santen, W. Samojlik, and S. A. Wells. 1982. How effective is surgical adrenalectomy in lowering steroid hormone concentrations? J. Clin. Endocrinol. Metab. 54:22-26.

9. Urban, M. D., P. A. Lee, J. P. Gutai, and C. J. Migeon. 1980. Androgens in pubertal males with Addison's disease. J. Clin. Endocrinol. Metab. 51:925-929.

10. Bongiovanni, A. M. 1981. Acquired adrenal hyperplasia: with special reference to $3 \beta$-hydroxysteroid dehydrogenase. Fertil. Steril. 35 : 599-607.

11. Beierwaltes, W. H., J. C. Sisson, and B. Shapiro. 1984. Diagnosis of adrenal tumors with radionuclide imaging. Spec. Top. Endocrinol. Metab. 6:1-54.

12. Winkel, C. A., M. L. Casey, R. J. Worley, J. D. Madden, and P. C. MacDonald. 1983. Extraadrenal steroid 21-hydroxylase activity in a woman with congenital adrenal hyperplasia due to steroid 21-hydroxylase deficiency. J. Clin. Endocrinol. Metab. 56:104-107.

13. Vierhapper, H., W. Waldhäusl, and P. Nowotny. 1982. Gonadotrophin-secretion in adrenocortical insufficiency: impact of glucocorticoid substitution. Acta Endocrinol. 101:580-585.

14. Villee, D. B., and J. Fisher. 1975. The influence of ACTH on steroid synthesis in normal and abnormal testicular tissues. Adv. Enzyme Regul. 13:317-328.

15. Ney, R. L., R. N. Dexter, W. W. Davis, and L. D. Garren. 1967. A study of the mechanism by which adrenocorticotroic hormone maintains adrenal steroidogenic responsiveness. J. Clin. Invest. 46:1916-1924.

16. Dominguez, O. V. 1961. Biosynthesis of steroids by testicular tumors complicating congenital adrenocortical hyperplasia. J. Clin. Endocrinol. Metab. 21:663-674. 
17. Hamwi, G. J., G. Gwinup, J. H. Mostow, and P. K. Besch. 1963. Activation of testicular adrenal rest tissue by prolonged excessive ACTH production. J. Clin. Endocrinol. Metab. 23:861-869.

18. Fore, W. W., T. Bledsoe, D. M. Weber, R. Akers, and R. T. Brooks. 1972. Cortisol production by testicular tumors in adrenogenital syndrome. Arch. Intern. Med. 130:59-63.

19. Radfar, N., F. C. Bartter, R. Easley, J. Kolins, N. Javadpour, and R. J. Sherins. 1977. Evidence for endogenous LH suppression in a man with bilateral testicular tumors and congenital adrenal hyperplasia. J. Clin. Endocrinol. Metab. 45:1194-1204.

20. Landing, B. H., and E. Gold. 1951. The occurrence and significance of Leydig cell proliferation in familial adrenal cortical hyperplasia. J. Clin. Endocrinol. Metab. 11:1436-1453.

21. Wilkins, L., W. Fleischmann, and J. E. Howard. 1940. Macrogenitosomia precox associated with hyperplasia of the androgenic tissue of the adrenal and death from corticoadrenal insufficiency. Endocrinology. 26:385-395.
22. Keutmann, E. H., and W. B. Mason. 1967. Individual urinary 17-ketosteroids of healthy persons determined by gas chromatography: biochemical and clinical considerations. J. Clin. Endocrinol. Metab. 27: 406-420.

23. Bradlow, H. L., and T. F. Gallagher. 1959. Metabolism of $11 \beta$ hydroxy- $\Delta 4$-androstene-3,17-dione in congenital adrenal hyperplasia. $J$. Clin. Endocrinol. Metab. 19:1575-1580.

24. Goldzieher, J. W., and S. C. Beering. 1969. Metabolism of $11 \beta$ hydroxyandrostenedione, adrenosterone and hydrocortisone to urinary 11-oxy 17-ketosteroids. J. Clin. Endocrinol. Metab. 29:171-178.

25. Samojlik, E., M. A. Kirschner, D. Silber, G. Schneider, and N. H. Ertel. 1984. Elevated production and metabolic clearance rates of androgens in morbidly obese women. J. Clin. Endocrinol. Metab. 59: 949-953.

26. Meikle, A. W., J. D. Stringham, D. E. Wilson, and L. I. Dolman. 1979. Plasma $5 \alpha$-reduced androgens in men and hirsute women: role of adrenals and gonads. J. Clin. Endocrinol. Metab. 48:969-975. 